\title{
BOEKBESPREKING
}

\section{Herstelrechtelijke rituelen: maximalisatie van emoties?}

Bas van Stokkom

Meredith Rossner, Just Emotions. Rituals of Restorative Justice, Oxford: Oxford University Press 2013, 183 p., ISBN: 978-0-19-965504-5.

Just emotions is een ambitieuze studie. De auteur beoogt de interactiepatronen van herstelrechtelijke conferenties bloot te leggen en te laten zien dat conferenties met een hoge mate van solidariteit tot aanzienlijk minder recidive leiden dan conferenties met een lage mate van solidariteit. Het is een merkwaardig onderzoek, omdat de auteur suggereert dat succesvolle conferenties afhangen van juiste soorten emotionele uitingen en dat die uitingen ook kunnen worden gepland. Ze lijkt de mogelijkheden van wat deze conferenties zouden kunnen bereiken te overschatten.

De auteur, docent criminologie aan de London School of Economics, heeft herstelrechtelijke conferenties als rituelen bestudeerd, waaronder gebaren, manieren en het ritme van de conversatie. Voortbouwend op het werk van Thomas Scheff en Randall Collins, onderzoekt de auteur wat er gebeurt op het microniveau van een conferentie: de bijeenkomst zelf en de situationele dynamiek, en vooral 'de belofte van emotionele transformatie'. De auteur maakt gebruik van gemengde onderzoeksmethoden, met inbegrip van een analyse van de waargenomen dynamiek van conferenties die plaatsvonden bij de Metropolitan Police in Londen, en een kwantitatieve analyse van systematisch waargenomen interacties die werden onderzocht in een eerder gepubliceerde Australische studie (RISE).

In het inleidende hoofdstuk suggereert Rossner dat de details van de criminaliteit, de kenmerken van de deelnemers en andere achtergrondvariabelen niet de belangrijkste factoren zijn die de slagingskans van een conferentie bepalen. Eerder hangt slagen af van ritueelopbrengsten zoals groepssolidariteit en cohesie. 'I will argue that the emotional and ritual dynamics within a restorative justice conference hold the key to understanding, monitoring, and measuring its success' (p. 11). Deze groepssolidariteit heeft verreikende gevolgen: 'It (...) is translated into long-term emotional well-being and the potential for reduced offending' (idem).

In de volgende hoofdstukken wijst ze erop dat emoties het hart vormen van het herstelrecht. Emoties zijn volgens haar goed, omdat ze bijdragen aan het proces van helen bij slachtoffers en regelnaleving bij daders. Rossner beoogt een diep- 
gaande analyse te bieden van de manier waarop dit gebeurt. Maar tegelijkertijd kijkt ze naar de microstructuur van de interactie. Succes betekent ritueel succes.

Hoofdstuk 4 is een case study van één enkele conferentie uitgevoerd bij de Metropolitan Police. Deze zaak - geheel gefilmd - bevat een gedetailleerde microanalyse die goed inzicht verschaft in de emotionele dynamiek, de keerpunten en de manieren waarop signalen van de deelnemers de emotionele dynamiek veranderen. De auteur onderzoekt ook macht- en statusonevenwichtigheden en de impact van deze onevenwichtigheden op de deelnemers. Een belangrijke component is de vorming van een interactieritme, een ritmiek die de deelnemers meevoert ('entrainment').

In hoofdstuk 5 toont de auteur hoe begeleiders de deelnemers voorbereiden op het 'maximaliseren van hun emoties' en het overnemen van rollen, en hoe zij strategieën gebruiken om de deelnemers te betrekken bij de conversatieritmiek. Dit hoofdstuk maakt gebruik van kwalitatieve interviews met begeleiders van de conferenties in Londen. Alle begeleiders zeiden dat de conferenties die voor de partijen het meest emotioneel intens waren, de beste conferenties waren. De auteur benadrukt dat het uiten van emoties verwelkomd moet worden, ook voorafgaand aan de bijeenkomst, maar tegelijkertijd zegt ze dat de begeleiders 'an aura of calmness and control' zouden moeten aanmoedigen, 'to ease the anxiety or impatience of the participants' (p. 82). Succesvolle rituelen produceren gevoelens van groepssolidariteit, een gedeelde moraal en emotionele energie. Tijdens niet-geslaagde rituelen is er geen ritme; de deelnemers voelen zich de hele tijd ongemakkelijk; er is geen dramatisch keerpunt.

In de hoofdstukken 6 en 7 worden deze vooronderstellingen empirisch getoetst. Hoofdstuk 6 presenteert de kortetermijnresultaten van succesvolle conferenties. De auteur heeft de variabelen van het interactieritueel aan een kwantitatieve toets onderworpen, waarvoor zij de systematische observaties van RISE (re-integrative shaming experiments) in Canberra heeft benut. Ze heeft een model van interactierituelen ontwikkeld waarin een hoge mate van evenwicht en lage niveaus van stigmatisering en verzet zullen resulteren in een hogere mate van solidariteit, re-integratie en emotionele energie. Deze positieve resultaten worden inderdaad door het model voorspeld. Een belangrijke bevinding is dat individuele kenmerken als etniciteit, leeftijd en geslacht niet van invloed zijn op de ritueeluitkomsten.

De volgende vraag is hoe dit interactieritueel crimineel gedrag beïnvloedt. Is het aannemelijk dat een intens en emotioneel krachtige conferentie het toekomstige gedrag van een dader kan beïnvloeden, ook in de periode na de interactie? Deze intrigerende vraag wordt behandeld in hoofdstuk 7 en de auteur veronderstelt dat krachtige rituelen inderdaad deze impact op lange termijn kunnen hebben. Ze analyseert recidivecijfers, wederom met behulp van de RISE-waarnemingen, en toont aan dat de situationele en rituele aspecten van een conferentie significante effecten kunnen hebben op de vermindering van criminaliteit. Niettemin zijn de resultaten raadselachtig: terwijl conferenties met een hoge mate van solidariteit 
significant verband houden met minder criminaliteit, leiden conferenties met een hoge mate van re-integratie tot meer criminaliteit. Anders dan zij veronderstelde, bleek emotionele energie geen significante variabele te zijn met betrekking tot recidive. De auteur suggereert dat emotionele energie uitblust wanneer die niet versterkt wordt in vervolginteracties. Rossner biedt interessante verklaringen voor deze wisselende resultaten.

De auteur verdient lof voor de zorgvuldige wijze waarop zij interactierituelen heeft geanalyseerd. Het is een rijk boek met uitstekende beschrijvingen, bijvoorbeeld over de manier waarop vrouwelijke deelnemers het emotiewerk van de conferentie op zich nemen en hoe de deelnemers subtiele tactieken benutten om hun status te verhogen. Het boek heeft een intrigerende titel die veel kantianen in de war zal brengen. Sommige moraalfilosofen menen dat emoties überhaupt niet kunnen bijdragen aan rechtvaardigheid. De auteur is wijselijk niet ingegaan op die discussie.

Het goede nieuws dat deze studie brengt, zo zegt de auteur, is dat de dynamiek van interactierituelen beïnvloedbaar is en kan worden gecontroleerd. 'A good facilitator can ensure the right ingredients are there to create a successful conference' (p. 142). De begeleiders hebben behoefte aan 'high level skills in understanding and managing the micro dynamics of emotion' (idem). Tegelijkertijd is het van belang dat zij 'maximize the expression of ... emotional displays through the build-up of anxiety, anger, and shame in the lead-up to the conference' (p. 80). De aandacht moet erop gericht zijn emoties boven water te halen: 'the stronger the emotions, whether they be positive or negative, the better the conference' (p. 81).

Hoe deze benadering van 'maximaliseren van emoties' te beoordelen? Ik denk dat het niet de bedoeling van conferenties kan zijn om al voorafgaand aan de bijeenkomst emoties te stimuleren. In die fase zouden begeleiders eerder respectvol en redelijk gedrag moeten benadrukken. Ook tijdens de conferentie zijn niet alle emoties welkom; veel negatieve emoties moeten worden ingeperkt. Ik geloof evenmin dat herstelrecht primair een energiek solidariteitsritueel hoort te zijn, maar eerder een zorgvuldig rechtvaardigheidsritueel. Het achterliggende perspectief van Rossner is de kneedbaarheid van collectieve gevoelens. Ze gaat echter niet in op de vraag of emoties als medeleven en spijt überhaupt het voorwerp van planning zouden kunnen of moeten zijn.

De auteur beweert dat de conferentie daders 'just enough' emotionele energie biedt om hen te motiveren te stoppen met criminaliteit (p. 37). Dit is niet geheel aannemelijk. Hebben we echt energieke conferenties nodig om gedrag te veranderen? Zou het niet mogelijk zijn dat daders die aan emotioneel 'oppervlakkige' conferenties deelnemen toch gestimuleerd worden om hun gedrag te veranderen? En andersom, zou het niet mogelijk zijn dat daders die deelnemen aan energieke bijeenkomsten deze rituelen achteraf als verstikkend of onderdrukkend ervaren? Belangrijker, zoals veel desistance studies aantonen: er is primair behoefte aan verandering van het 'zelf-narratief' en identificatie. 
Hoe de lage recidivecijfers na het bijwonen van een conferentie uit te leggen? Doet het 'entrainment-ritual' het werk, zoals Rossner suggereert? Het is mogelijk dat daders voorafgaand aan de conferentie al berouw voelden en met gedragsverandering bezig waren. Met andere woorden, daders die betrokken zijn bij rituelen met een hoge mate van solidariteit kunnen al vooraf weerspannige of onverschillige gevoelens hebben losgelaten. Als dit zo is, spelen individuele kenmerken een belangrijkere rol dan de auteur suggereert.

Onderzoekers kunnen conferenties opvatten als rituelen, maar de deelnemers ervaren deze bijeenkomsten waarschijnlijk op andere manieren: als gelegenheden om te zeggen wat hen dwars zit, om te vragen naar de motieven van de dader, en vooral om gerechtigheid te zoeken. De procedure kan geslaagd worden genoemd wanneer de herstelovereenkomst als rechtvaardig wordt ervaren. Als de deelnemers tevreden zijn over de afspraken, waarom zou je je dan zorgen maken over een tekort aan 'entrainment', ritme of onbalans tijdens de bijeenkomst? Echter, de auteur vindt dat de overeenkomst minder belangrijk is dan de emotionele interactie, culminerend in een gedeeld begrip van wat er tijdens de bijeenkomst is gebeurd. Als het slachtoffer daardoor in staat is om verder te gaan, is het resultaat van de overeenkomst secundair (p. 101).

Een laatste kritisch punt heeft betrekking op de taal die tijdens de bijeenkomsten wordt gebezigd. De auteur maakt niet echt een analyse van argumentatie en retoriek. Hoewel ze in de conclusie verwijst naar het belang van 'the invocation of symbols', ontbreekt dit aspect in haar onderzoek. Welke claims worden geuit en door wie? Welke betekenissen van rechtvaardigheid worden verwoord? Welke boodschap proberen de deelnemers over te brengen? Als we willen weten hoe ieders zelf-narratief verandert, is deze morele taal van groot belang.

Rossner heeft herstelrecht bestudeerd als ritueel. Dat is een veelbelovend perspectief en heeft denk ik meer te bieden dan een analyse gericht op emoties als schaamte en schuld. Helaas is het boek overambitieus. Het is niet overtuigend om vermindering van recidive in een model van interactieritueel op te nemen. Het internaliseren van regelnalevend gedrag en het afzien van criminele opties liggen voor een groot deel buiten de macht en mogelijkheden van een herstelrechtelijke conferentie. 